\title{
ECONOMIC ACTIVITY IN AGRICULTURE IN THE PERSPECTIVE OF EMBEDDEDNESS THEORY: THE CASE OF POLAND
}

\author{
Michat Dudek ${ }^{1}$
}

\section{Summary}

The paper presents the concept of embeddedness of economic activity in relation to agriculture. In this perspective, economic activity can be considered dependent on cognitive structures, structures of social relations, culture, and political institutions. It has been concluded that the idea of embeddedness can be an interesting and useful analytical tool for the analysis of economic activity undertaken by farmers. The article presents an analysis of the state of the art, as well uses selected information and data on the methodology of panel surveys carried out by the Institute of Agricultural and Food Economics - National Research Institute. Based on the analysis of the embeddedness theory, it is argued that embeddedness is not a coherent theoretical concept but rather a potential framework for investigating various economic issues. One of these issues is agricultural activity. Embeddedness framework constitutes a scheme which could organize an alternative approach to economic actions to mainstream agriculture economics.

Key words: embeddedness, economic activity, agriculture, farmer.

JEL: $Q 15, B 5, Z 13$.

1 Michał Dudek, MA, Institute of Agricultural and Food Economics - National Research Institute, Świętokrzyska Street no. 20, 00-002 Warsaw, Poland, Phone: +48 225054 578, E-mail: dudek@ierigz.waw.pl. 


\section{Introduction}

The term embeddedness ${ }^{2}$ became a keyword in social sciences, which was used to describe and analyse an individual's activity in the field of economy. This word refers to the model or a theoretic concept on the boundary between sociology and economics. The concept of embeddedness $s^{3}$ of economic activity should above all be placed in opposition to the mainstream economics that presents the vision of homo oeconomicus, i.e. an individual ${ }^{4}$ who is rational, has full information at their disposal on the market, who can prioritise their preferences, and makes optimal choices to maximise own utility regardless of their surroundings. In the paper agriculture activity is presented from the embeddedness perspective as a type of economic action.

Introduction of the term embeddedness to social sciences is commonly attributed to Karl Polanyi, who studied the subject of causes and effects of the development of modern market societies. According to this author, economic development in the age of the industrial revolution was accompanied by the process of removing market exchange from the influence of institutions (principles of mutuality of redistribution and self-sufficiency), which organised economic life of pre-capitalist societies. As a consequence of the subjection of life to the market model, the man and nature started to be treated as commodities, and interpersonal ties started to fall apart (Polanyi, 2010). It cannot be unambiguously determined whether the term embeddedness was used by the said author as a metaphor or a name of a theoretical concept. Indubitably, the latter kind of function started to be attributed to the said term by other researchers, who directly or indirectly referred to the Hungarian anthropologist's work, much later on.

The concept of the embeddedness of economic action is one of the key theoretical foundation of contemporary economic sociology. According to this idea the economic activity is determined by cognition, social structures, culture and politics. Selected theories are described, as well as empirical studies concerning setting up, running and maintaining an agricultural holding. In the first part of the paper the agricultural activity through the prism of classical microeconomic approach was described. Next the key foundation of embeddedness of economic action was presented. In the second part of the article we used basic assumptions of this concept to interpret and analyse an agriculture activity. For instance, basing on the Institute of Agricultural and Food Economics - National Research

2 Due to the cognitive and emotional connotations of the embeddedness, it is stressed that a more appropriate is writing this word in quotation marks or translating as rootedness or settlement (Chmielewski, 2010). Translating embeddedness as rootedness evokes associations with deterministic theories that define the man as a passive being that is totally dependent on the surroundings. It the perspective of the embeddedness paradigm, such an interpretation does not seem absolutely true. It is the other way round, emphasis on the importance of an individual's activity in the surroundings may be seen in the idea in question. Subject to this reservation, the word written in italic because this approach has become relatively more popular in the literature.

3 In this paper, the terms: concept, idea, perspective and paradigm are used interchangeably.

4 The terms individual and actor are used interchangeably. 
Institute (IAFE-NRI) surveys methodology we proposed an analytical model of farmer's position and actions within socio-economic structures.

\section{Literature review}

In the classic microeconomic approach, the agricultural producer (farmer), who is the manager of farm, strives for the maximisation of his/her goal function, i.e. achieving income at a satisfactory level. The implementation of this task depends on a number of decisions in the following areas: production type and volume, allocation of resources and inputs (financial means, work time, skills), uncertainty and risk (environmental and seasonal character of agricultural production) (Kowalski, Rembisz, 2003). It is often emphasised that in order to realise his/her production plans to the largest possible extent, a farmer can influence only one of the abovementioned areas, namely the allocation of resources and inputs, more precisely, in the area of work efficiency. Among the foundations of work efficiency there is the concentration of capital and the proper technical equipment of an agricultural farm. However, while analysing the situation of a farmer managing an agricultural holding, apart from the type and size of production, the division of inputs and resources, uncertainty and risk, the significant impact of a number of exogenous conditions must be included, i.e. social context, regulations and the institutional factor, infrastructure and the actions of other market participants, on the effects of production. In this respect the situation in the environment of an agricultural farm becomes more and more complex, not only because of the processes of growing competition and changing business cycles on agricultural markets, but also due to the necessity to adjust to the changing consumer needs, as well as agricultural policy, systematically increasing the requirements for producers (those requirements mainly concern manufacturing agricultural products and their quality). As a result, each activity in the field of economy, for example running a farm, is not fully independent. It is influenced by four limiting elements: the human cognitive structure, the structure of social relations, culture, and political institutions (DiMaggio, Zukin, 1990). Therefore, four types of embeddedness could be distinguished: cognitive, structural, cultural, and political.

Cognitive embeddedness refers to the way the human mental processes are structured. When the situation is uncertain and complex, and cost of obtaining information is high, which occurs on the market, an individual's rational activity is limited. The existence of such barriers has been proved by research in the field of decision theory and cognitive psychology. An example of limits to human mental processes are decision heuristics: representativeness, availability, and anchoring, which are used when an individual is in doubt. The representativeness heuristic regards the determination of the chance that a defined event (event A) occurs based on the degree of similarity between event A and event B (most often, it is a typical case, which is known). The availability heuristic consists in estimating the probability of a specific event based on facts that may be easily evoked from memory. Finally, the anchoring heuristic concerns the distorting impact of the arbitrarily accepted values (starting points) on further estimates (Tversky, Kahneman, 1974). They result in saving time, and they are usually effective, but, 
as proved by experiments, they cause systematic and predictable errors (Tversky, Kahneman, 1974).

Cultural embeddedness regards collective convictions that influence individual strategies and objectives of economic nature. Regardless of the ambiguity of culture as a concept, it should be accepted that the term can be applied to its regulative, motivational or informative aspect, i.e. generally accepted norms, values, behavioural patterns, and not the constitutive aspect in the sense of cognitive embeddedness (Dequech, 2003). Emphasis on the economic aspect of the latter may be particularly useful in the analysis of mutual influence between economy and culture. Economic culture encompasses value systems, behavioural patterns and cognitive schemas that are related to the economic activity. Value systems define what is desirable or unacceptable in a specific community. Behavioural patterns refer to internalised norms and habits that influence human behaviour. Finally, the cognitive models constitute a category, which is used by people to interpret reality, particularly in its economic aspect (Marody, Kochanowicz, 2007).

Structural embeddedness regards perception of economic activity through patterned and lasting interpersonal relations (Granovetter, 1985). In this view, actors do not make decisions in their purposeful activities independently of their environment, but are neither subjected to it. Due to social interactions, which then result in business contact, it is possible to, e.g., acquire relatively more relevant and cheaper information that are necessary from the perspective of one's activity, establish mutual trust between parties to a transaction, which limits possible opportunism or abuse, or a relatively higher level of legitimisation of the surroundings. The type of embeddedness in question refers to a structural paradigm where the principal axis of reflection is the network, i.e. patterns of ties between entities that influence the ways various resources are allocated between them (Wellman, 1988).

The last kind of embeddedness is political embeddedness, which concerns the asymmetry of power, influence, or strength between entities (DiMaggio, Zukin, 1990). Inequalities of this kind define the manner resources are allocated, and they may result from various causes. First, they are related to the legal and institutional system in which the individual functions. A specific legal and institutional system may favour selected entities at the expense of other. Second, one actor's advantage over another is often related to unequal distribution of resources such as money, technology, or information. Third, asymmetry of power is related to the level of social legitimisation (Beckert, 1999).

Based on the analysis of the embeddedness theory, it should be argued that embeddedness is not a coherent theoretical concept but rather a potential framework for investigating various economic issues. It constitutes a scheme which could organize approach to economic activity in a way alternative to economics. 


\section{Data and methodology}

The aim of the study is to present a specificity of economic activity from the perspective of the concept of embeddedness. The type of action that has been selected for analysis is agricultural activity undertaken by the farmer (manager of agricultural holding), with particular attention to the Polish context. The basis for the presented analysis is the assumption that any activity in the field of economy is conditioned by cognitive structures, social relations, culture and political institutions, which has been derived from the idea of embeddedness.

The main source of the presented reflection has been the analysis of literature regarding economics and sociology. For the definition of socio-economic environment of farm managers in Poland the methodology of panel surveys conducted by the IAFE-NRI has been used in this study. This surveys are multi-annual studies and are conducted periodically in the same villages, in all local farms owned by natural persons, with an area of more than 1 ha of agricultural land. The villages were specially selected to make the size of the analysed farms representative to the actual Polish agrarian structure, both at the national and macroregional level. In IAFE-NRI surveys one of the research tool is a questionnaire for farming families (Family and the Farm). This questionnaire is designed to collect a great variety of detailed information, not only on the features of agricultural holding, but also on the socio-demographic characteristics, the educational level, economic activities of managers and members of their families (Sikorska, 2013). The gathered information concerned also the selected characteristics of production units, particularly on its area, equipment with fixed production assets, the scale of production, market and investment activity, as well as sources of financing activities.

The indicated type of information has been used to prepare the model of social embeddedness of a farmer's economic activity (a model-oriented approach) The schema has the form of an ego network and covers potential social relations with the social and institutional environment that can be relevant to agricultural production at the microeconomic level. The ego network concerns social relations established with actors from the perspective of an individual (focal node). Information on the ego network is useful for the comprehension of the way the surroundings influence individuals and provide a fragmentary image of the entire structure of social relationships (Hanneman, Riddle, 2005).

\section{Results}

In the perspective of the concept of cognitive embeddedness, agricultural activity, as well as any other activity in the field of economy, should be deemed to be affected by errors. Such errors may result from a number of factors. First, agricultural producers are threatened with increasingly numerous market risks, which cause a significant level of uncertainty. Apart from the biological and natural factors that are relevant to agricultural production (production risk), the doubt is increased by specific macroeconomic conditions that influence demand for agricultural raw materials and the 
cost of capital (price risk), collective, often irrational, behaviour of other participants in the market, and changes in the agricultural policy (Hamulczuk, 2009). In the perspective of findings related to climate change, it should be deemed that the risk related to agricultural activity due to biological and natural factors such as temperature or extreme weather phenomena is not constant, but is increasing as the pollution of the natural environment increases (Stern, 2009). In many cases, farmers have insufficient information on current and future market conditions for production (supply, demand, price), existing and proposed legal regulations, the existing instruments of agricultural policy, and changes to them. Such knowledge would make it possible to take proper decisions both in the shorter and in the longer perspective. However, collecting and processing large quantity of data is too expensive, and the situation in the surroundings of people managing farms, as well as other organisations, becomes more and more complex. In general, it is impossible to adjust to market conditions in a short term because it would require changes to the production process through additional investments, whose implementation exceeds a single production period. An additional barrier for earning the assumed income from the farm are limits to the cognitive process, such as the decision heuristics that have been described above.

Considering the importance of culture for the production of goods and services is aimless from the perspective of classical and neoclassical economics. A farmer who has complete market information takes rational decisions with regard to what, when, how and how much to produce and at what price to sell the produced raw materials to ensure the achievement of one's own objective in the form of satisfactory income from the farm. From the perspective of the concept of embeddedness, we deal with a view on the situation that is different from the one described above. A specific kind of national, regional or local culture shapes a dominant orientation towards the field of economy. The set of values and norms of behaviour at a specific level translates into one's image of economy, interpretation of phenomena in this field, as well as the form and scale of activity that is referred to as entrepreneurial activity (Glinka, 2008).

As far as Poland is concerned, it should be assumed that there is no uniform economic culture. Its diversity may be related to the spatial, social or economic aspect. What is more, it may be diverse within specific categories of people. In this context, various orientations towards economic activity can be recognised among farmers. For example, the tendency is illustrated by the frequently observed division into industrial (commercial) farms and farms with social functions (semi-subsistance farms) (Halamska, 2009). The farmers of the former category implement the model of entrepreneurial activity. In this case, the purpose of farming is profit and effective use of resources, not necessarily used on the basis of ownership. The group in question is often characterised by narrow specialisation of production and striving for its continuous development. As far as the nature of family is concerned, this orientation is the field of competition between generation and high level of independence among the young, which can sometimes contribute to lack of successors. A different attitude towards agricultural activity accompanies the latter model - the family farmer model (not market oriented farms), 
This model refers to farmers who treat the agricultural holding as a place of residence, traditional workplace, a means of providing food, social security or supplementing income. The main goal is not profit, but continuation of the farm's existence. Usually, such farms produce a diversity of agricultural products on a small scale (often not for the market but family use). Cooperation between generations is the dominant model in the group in question. Parents support their children's occupational orientations (non-agricultural mostly), they retire relatively earlier and transfer production assets within the family (Gorlach, 2004). It seems that the latter model is relatively common in Poland.

In the perspective of structural embeddedness, a farmer's economic activity may be discussed as a system of relations that link them with diverse entities. According to this paradigm, it can be assumed that the specific position and activity of a user of a farm in the network, as well as the features of that network, translate into specific effects of the activity (Witt, 2004). The presence of this relation depend on, e.g., type of ties that have been developed embedded or arm's length ties and their distribution. The research shows that a balanced structure of embedded ties based on extended social contact and arm's length ties (short-term market transactions) positively impacts the achievement of the intended economic results (Uzzi, 1997). Apart from material resources, important features include the possibility to acquire and develop such elements as reputation, contact with business partners, suppliers, and advisers. It should be supposed that if a farmer's position in the network and their structure of relations is more extensive and diverse, support they receive from it is greater. In the model structure of the studied farmers' ego network, which was recreated based on the methodology of the research by the IAFENRI a significant number of actors of economic significance for the agricultural activity has been identified (fig. 1). Links or nodes represent various types of flow: goods, money, services, or information. 
Figure 1. Structural embeddedness of the farmer's economic activity ${ }^{5}$

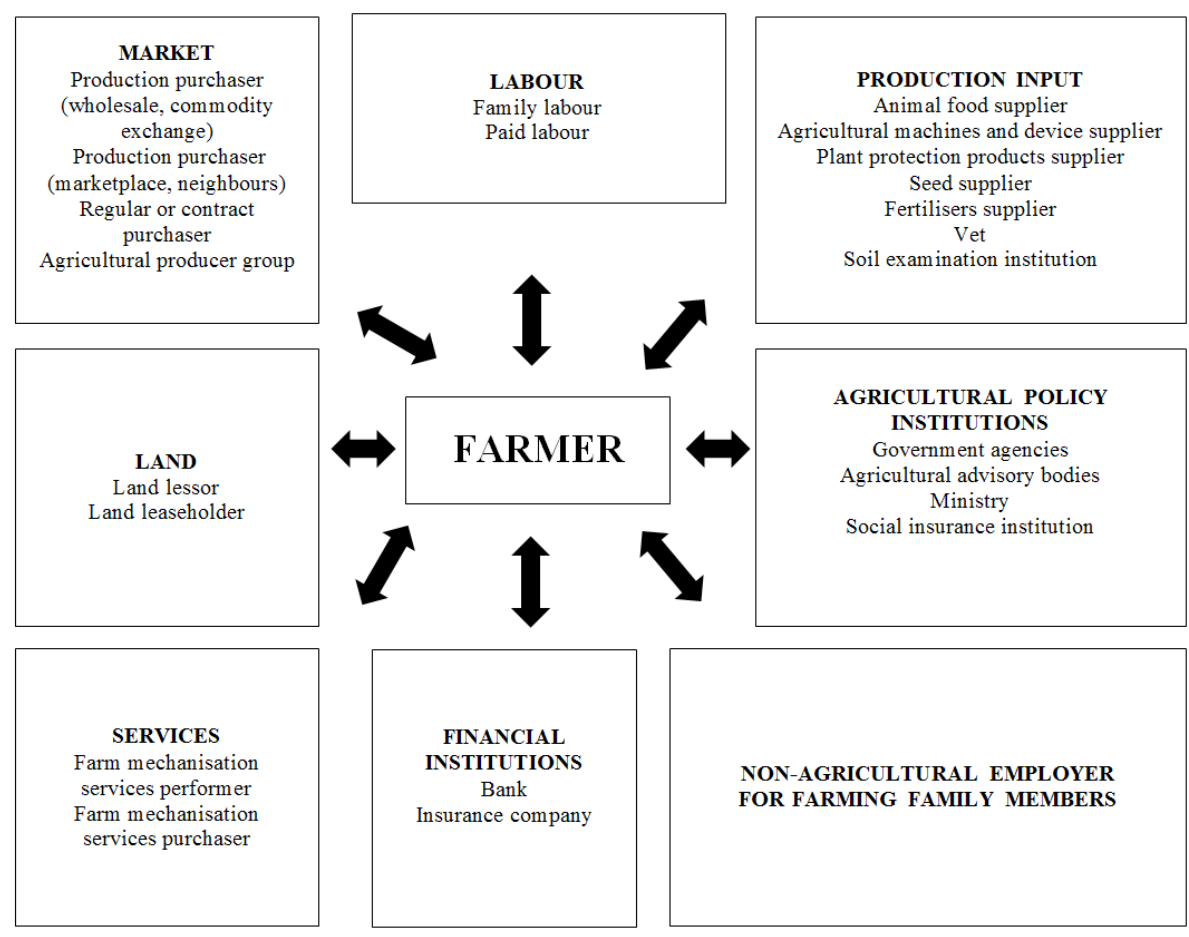

Source: own elaboration based on the research of IAFE-NRI.

Political embeddedness in relation to agricultural activity can be examined from a variety of perspectives. Agriculture as a sector of intense public support can be treated as a field of decision taken as a result of public choice under the political system and by political institutions (Wilkin, 2008). For example, one of the aspects of the problem is related to the issue of legitimisation of agricultural policy in most highly developed countries. Subsidies for producers of agricultural raw materials leads to opposition by other social groups such as taxpayers or food consumers in those countries. What is more, it is stressed that subsidising agriculture in rich countries is a barrier for economic growth in poor countries that could base their export on those goods (Kowalski, 2010). Another symptom of political influence on agricultural activity can be the shape of agricultural and rural development policy at the national and the EU level. Research shows that CAP reforms (and, as a consequence, the structure of tools of that policy) are strongly influenced by political pressure. Thus, there is a tendency to avoid responsibility for one's decisions and to transfer them to other institutions among policy-makers (Daugbjerg, Swinbank, 2007). Furthermore, the aspect of CAP in question can be reflected by unequal distribution of resources or development opportunities among the beneficiaries. It is estimated that the majority of funds under

5 The diagram of the farmer's immediate surroundings includes selected items. 
the system is received by a small portion of producers (Kowalski 2010). This fact can be interpreted as the activity of various interest groups and the so-called distributional coalitions, which are interested in the introduction of legislative solutions that are most beneficial in their perspective or the implementation of a specific public fund allocation mechanisms (Wilkin, 2008).

\section{Conclusion}

The perspective of embeddedness is an interesting theoretical model whose purpose is analysis of activity undertaken in the field of economy. It is opposed to the concept of a rational actor, which is the basis of the mainstream economics. Embedded economic activity is seen as dependent on cognitive structures, social relations, culture, and politics. Activity that consists in running a farm is characterised by a number of shared regularities compared to other market activities. Just like in the case of other types of actors, the barrier for a farmer's rational behaviour are decision heuristics. On the other hand, the specific nature of agricultural production may be its strong dependence on biological and natural factors, which influence the complexity of the situation and increase uncertainty. From the perspective of the concept of embeddedness, the outcomes of production may be conditioned by the structure of the farmer's social relations. An actor's position in the network, the features of the network, types of ties or kinds of activity translate into the availability of resources and opportunities related to a business enterprise. Based on research by the IAFE-NRI, a model of studied farmer's social and institutional relations that are relevant to farming has been should be considered as complex. The model includes a significant number of entities in the nearest surroundings of the agricultural holding's managers. In the analysed perspective, culture should be deemed as an important factor that affects goals and strategies in running agricultural activity. It is reflected by various attitudes towards one's own production assets among farmers. Moreover, agriculture is a sector which is shaped by political institutions. Thus, activity within it is related to functioning under a conflict with regard to specific ways conditions for production are arranged or resources are allocated.

\section{Literature}

1. Beckert, J. (1999): Economic action and embededdness: the problem of structure of action, paper presented at the 11th Annual Meeting of Socio-Economics in Madison, the meeting in European Sociological Association in Amsterdam and a colloquium at the Free University of Berlin, pp. 34-35.

2. Chmielewski, P. (2010): Umiarkowany metodologiczny indywidualizm: przezwyciężenie tradycyjnego sporu między holizmem i indywidualizmem $w$ naukach społecznych, in Jednostka zakorzeniona? Wykorzeniona?, Lompart, A. (ed.), Instytut Socjologii UW, Wydawnictwo UW, Warszawa, pp. 51-52.

3. Daugbjerg, C., Swinbank, A. (2007): The politics of CAP reform: trade negotiations, institutional settings and blame avoidance, Journal of Common Market Studies, Blackwell Publishing Ltd, vol. 45, no. 1, p. 19.

EP 2016 (63) 1 (205-215) 
4. Dequech, D. (2003): Cognitive and cultural embeddedness: combining institutional economics and economic sociology, Journal of Economic Issues, ABI/ Inform Global, p. 464.

5. DiMaggio, P., Zukin, S. (1990): Structures of cappital. The social organization of the economy, Cambridge University Press, p. 15-19.

6. Glinka, B. (2008): Kulturowe uwarunkowania przedsiębiorczości w Polsce, Polskie Wydawnictwo Ekonomiczne, Warszawa, pp. 10-11.

7. Gorlach, K. (2004): Socjologia obszarów wiejskich. Problemy i perspektywy, Wydawnictwo Naukowe Scholar, Warszawa, p. 250.

8. Granovetter, M. (1985): Economic action and social structure: the problem of embeddedness, American Journal of Sociology, The University of Chicago Press, vol. 91, no 3, p. 490.

9. Halamska, M. (2008): Pięć lat w UE: stare i nowe procesy zmian na polskiej wsi, Wieś i Rolnictwo, IRWiR PAN, Report no. 143, No 2, Warszawa, p. 62.

10. Hamulczuk, M. (2009): Analiza, prognozowanie i zarządzanie ryzykiem cenowym na podstawowych rynkach rolnych - możliwości stabilizowania dochodów producentów rolnych. Synteza wyników badań prowadzonych w latach 2008-2009, IAFE-NRI, Report no. 149, Warszawa, p. 11-18.

11. Hanneman, R. A., Riddle, M. (2005): Introduction to social network methods, Riverside, CA, University of California, Riverside, p. 9.

12. Marody, M., Kochanowicz, J. (2007): Pojęcie kultury ekonomicznej w wyjaśnianiu polskich przemian, in Kulturowe aspekty transformacji ekonomicznej, Kochanowicz, J., Mandes, S., Marody, M. (eds.), Instytut Spraw Publicznych, Warszawa, p. 19.

13. Kowalski, A. (2010): Dlaczego Polska nie powinna zgodzić się na denacjonalizację Wspólnej Polityki Rolnej, Opinie i ekspertyzy, OE-124, Kancelaria Senatu, Warszawa, p. 4.

14. Polanyi, K. (2010): Wielka transformacja, Wydawnictwo Naukowe PWN, Warszawa, p. 51.

15. Sikorska, A. (2006): Przeobrażenia w strukturze spoleczno-ekonomicznej wsi objętych badaniem IERiGŻ-PIB w latach 2000-2005, Projekt badawczy nr H02C 035 28, IAFE-NRI, Warszawa, pp. 5-10.

16. Tversky, A., Kahneman, D. (1974): Judgements under uncertainty: heuristics and biases, Science, New series, vol. 185, no 4157, American Association for the Advancement of Science, pp. 1130-1131, 1124, 1128-9.

17. Stern, N. (2009): Ekonomia zmian klimatycznych - podsumowanie raportu in Ekologia. Przewodnik Krytyki Politycznej, Wydawnictwo Krytyki Politycznej, Warszawa, p. 180.

18. Uzzi, B. (1997): The sources and consequences of embeddedness for the economic performance of organization: the network effect, American Sociological Review, vol. 61, American Sociological Association, pp. 684-685.

19. Wellman, B. (1988): Structural analysis: from method and metaphor to theory and substance, in Social structures: a network approach, Wellman B., Berkowitz S.D. 
(eds.), Cambridge, Cambridge University Press, s. 20.

20. Wilkin, J. (2008): Ekonomia polityczna systemu wsparcia bezpośredniego $w$ ramach WPR, ze szczególnym uwzględnieniem sytuacji $w$ nowych państwach czlonkowskich UE, http://ec.europa.eu/budżet/reform, pp. 1-4, 01.04.2011.

21. Witt, P. (2004): Entrepreneur's networks and success of start-ups, Entrepreneurship and regional development no 16, Routledge, Tylor and Francies Group, pp. 391-398. 